\title{
Relating Smart Governance as a University Feature to Students' University Perceptions
}

\author{
Mario Jadrić \\ Faculty of Economics, Business and Tourism \\ University of Split, Croatia \\ Maja Ćukušić \\ Faculty of Economics, Business and Tourism \\ University of Split, Croatia

\section{Tea Mijač} \\ Faculty of Economics, Business and Tourism \\ University of Split, Croatia
}

mario.jadric@efst.hr

\begin{abstract}
Following the results of recent studies on the creative use of smart technologies in urban and university settings, there is a growing number of promising research areas under smart university as an umbrella term. Starting from the differentiation between six standard "smart" dimensions in the university, the paper focuses on one smart university feature in particular - it explores the level and the relation of smart governance to the attitudes towards university management, fellow students, and Perceived External Prestige (PEP) as antecedents of university affective commitment. The paper presents multivariate analysis results based on the feedback from over 400 students. Participants were first-year students from the second biggest university in Croatia. While the effect of smart governance on the positive attitude towards university management is found to be positive and significant, the effect of the perception of university management on students' university commitment is low and not significant in the given context.
\end{abstract}

Keywords: Smart University, Smart Governance, University Commitment

\section{Introduction}

The level of technological provision in everyday activities continually evolves with the emergence of new concepts and tools that impact all aspects of our lives. In Higher Education (HE) settings, the change in the way the individuals interact in the university environment is well-acknowledged according to Smyrnova-Trybulska [1], understanding that to stay competitive on a global level, the changes must be reflected in the university organization [2]. In particular, the availability of certain technologies should reflect on how the relevant processes should be performed and what high- 
quality services should be offered [3]. The imperative for change did not bypass the HE institutions in Croatia either. In particular, two goals from the currently valid national strategy for education and technology, which are aligned within these given settings, could be highlighted [4]: (1) Increasing the quality of student life and internationalization of $\mathrm{HE}$ and (2) Improving the information and communication infrastructure. Identified challenges have been addressed at the university level, prompting, for example, the University of Split to set its aim to become the leading regional university in this part of Europe while pointing out that the key tasks are to conduct teaching, scientific research, artistic creation and professional activity, based upon principles of quality control and assurance and the EU standards [5].

To help cope with related challenges, the area of research, design, and development of smart universities has become central to various pioneering (inter)national studies, events and projects, governmental and corporate initiatives, institutional agendas, and strategic plans [2]. Specifically, in November 2019, over 6.800 papers (excluding citations and patents) were available after performing a search via Google Scholar, a bibliographic search engine on topics "smart university" or "smart campus" [6], while in March 2021, the number of papers is almost 8.600. Even though smart universities' primary focus is in the area of education, other aspects, for instance, management, require radical change [7]. Education is just the upper layer, and other aspects must be considered, such as [2]: (1) communication; (2) social interaction; (3) transport; (4) management; (5) wellness (safety and health); (6) governance; (7) energy management; (8) data storage and delivery; (9) knowledge sharing; (10) IT infrastructure, and (11) environment.

The rationale behind universities' tendencies to become smart is convincing - the aspiration is not only to increase efficiency but also to improve the experience for students and staff [8]. Providing a better experience for students could become the main element that helps them distinguish their offerings from the competition to attract and retain the best students and staff internationally. It could become a challenge since the goal is to satisfy new generations of students who are very connected, informed and stay in touch with the outside world [7].

The study presented in the paper builds on the two presented aspects - increasing the number and organization of smart university features with the purpose to increase the quality and personal experiences on the one hand, and the students' opinions about the university resulting in varying levels of commitment and affection on the other hand. More specifically, the aim was to explore how smart governance, perception of fellow students, attitude towards university management and perceived external prestige affect students' university commitment. The study's theoretical background is presented in Section 2, followed by the methodological considerations that were taken into account for results analysis in Section 3. The results are presented in Section 4, and the discussion and conclusion in Sections 5 and 6, respectively.

\section{Research Model and Hypotheses Development}

The research model is based on the one introduced by Udir Mišič and Podnar [9]. Their model was tested with citizens from two cities when the results showed that 
Perceived External Prestige (PEP) and the Perception of fellow residents of the city were significant drivers of City commitment. Also, Perception of city management has a significant impact both on Perceived External Prestige and on the Perception of fellow residents, without a significant direct effect on City commitment. The reasons for testing the variables of the model that was tailored to a city context in the HE context has been elaborated in another paper [6]) already. In general terms, the potential of campuses to serve as valuable (smart) city prototypes is widely recognized, mostly due to a growing need for conducting more focused research in the smart city domain as it grows more mature. Also, in the introductory part of this paper, the key reasons for assessing the technological advances in relation to improving student experiences and university commitment are given. That is why the original model of city commitment was contextualized and extended to include the technological aspect. Out of the six well-known smart city characteristics introduced by Giffinger et al.[10], presumably, smart governance could significantly impact the attitude towards university management, fellow students, and Perceived External Prestige - and therefore, an indirect impact on students' university commitment. The reasons for these assumptions and specific hypotheses are given in the following.

\subsection{Students' University Commitment (Affective Commitment)}

Students' commitment reflects their overall satisfaction, sense of belonging, perception of educational quality, and willingness to attend the university again [11]. It is defined as the firm belief in acceptance of the university and also presents a desire to maintain a long-term relationship with a specific university [12], [13]. A survey conducted at the University of Split, Faculty of Economics, Business and Tourism, showed that dropout rates are the highest among first-year students, which could point out that HEIs need to put more effort into improving the efficiency of educational processes [14]. Students' commitment reflects the student's motivation to continue the relationship with the university, noting that high reputation and trustable universities have a positive effect on students' commitment [13]. The level of students' commitment rises when students believe they have an opportunity for improvement within the university, as well as when they feel they have become key stakeholders [12]. Here, it is important to distinguish between normative commitment and affective commitment [15]. The affective commitment represents an emotional attachment (feelings of inspiration, pride, belonging, and so on), while normative commitment represents a feeling of obligation [16], [15]. For example, if a student remains with the university because they want to - it denotes affective commitment. Opposite of that, students with strong normative commitment will remain with the university because they feel that they ought to do so [15]. Affective commitment is indeed a meaningful concept within HE since it contributes to a sense of care towards the university and a desire to stay connected [16]. The importance of students' commitment has been recorded long-ago: Tinto [17] stressed that students achieving a higher level of social and academic integration have stronger goal commitment and institutional commitment - resulting in a lower retention rate. Recent research showed that the relationship between students' university commitment and students' 
effectiveness could also play an important part in the enrolment, financial planning, and management of the university [18] or, to put it differently, the commitment not only affects individuals' outcomes but also impacts the organizational/university outcomes [12]).

\subsection{Attitude Towards University Management}

Universities worldwide are facing management problems such as [19]: (1) unbalanced growth in the number of students, (2) infrastructures that cannot keep up with the enrolment growth, (3) increased student/faculty ratios, (4) quality of education, (5) heavy competition for limited funding for research, and (6) heavy competition between the universities. At the same time, university management has a great responsibility as it has to maximize the impact on society through supervision and promotion of knowledge creation and science research [20]. In the literature related to smart universities and smart campuses, the management aspect is often highlighted as one of the main areas where changes are needed [21], [22], [23]. The importance of using technologies for data management to store, manage and use (big) data for providing an accurate basis for university management [24] is another promising research area with more and more evidence from real-life implementations [25]. The improvement in the efficiency of university management, for example resulting from the performance of an integrated information system, can improve various aspects of the educational process, automate administrative and business activities and financial management as well as provide information support to decision-making in all areas of the university [26], and, above all, contribute to better student experiences. The changes in university management can help address the identified challenges, resulting in better performance of the university, and, consequently, in developing feelings of pride in the student population, a sense that can be linked to commitment construct [16]. A hypothesis is formulated:

H1. Positive attitude towards university management will have a positive impact on students' university commitment.

\subsection{Perception of Fellow Students}

Another aspect deemed important for students' university commitment is the perception of fellow students. As mentioned before, affective commitment is related to emotional attachment [16]. Students find the opinions of close people relevant; for example, the commitment of students and their parents to obtaining a HE degree significantly relates to whether or not the students persist beyond their freshman year [27]. The same has been confirmed in recent years. Opinion about fellow students, such as negative impressions of them, increases the likelihood of first-year students dropping out [28], i.e. disliking them is considered one reason for a voluntary drop out [29]. Academic and social integration were the two most important factors in the retention of students [30]. As a part of social integration, the quality of the individual's relationships with fellow students (regular contacts) and with lecturing staff (especially informal interactions) are considered essential [29]. Nowadays, 
communication and regular contact are simplified - students have easy access to information they need, and they are connected 24/7 [7] with different university fellow groups for assistance, sharing and discussion or just staying informed [31]. This includes information about the university and its management structures that could lead to a sense of pride. Here, it is important to note that there is a great deal of research on marketing and mass communications identifying conditions under which group opinions influence individuals [32]. One of the conditions under which group opinions are more likely to persuade individuals is when the audience is younger, a point in the case when considering the student population [33]. Consequently, two hypotheses are formulated:

H2. Positive attitude towards university management will have a positive impact on the perception of fellow students of the university.

H3. Perception of fellow students of the university will have a positive impact on students' university commitment.

\subsection{Perceived External Prestige}

Analogously, acknowledging the importance of other people's opinions but in a slightly narrower approach, the term perceived external prestige is examined. The concept refers to organizational members' perceptions of how prestigious the organization is in external stakeholders' eyes [34]. It stands for what an individual thinks outsiders view his or her organization (and therefore, him- or herself as a member) [35], [36]. Authors Sung and Yang highlight that perceived external prestige is an individual-level variable [37] primarily because it is based on individual's interpretations and assessments of their organization's prestige, based on their exposure to information about the organization [34]. Due to this personal approach, members of the same organization may have different perceptions of its external prestige [37]. Perceived external prestige answers the question, "what do outsiders think of me because I belong to this organization?" [35]. The higher the organization's prestige, the more likely it is for the individual to identify with the organization because the affiliation to the organization enhances their self-esteem [37]. Many researchers in the field assumed that perceived external prestige influences an individual's behavior due to their identification with the organization and have found, in different contexts, that perceived external prestige leads to individuals' affective commitment [38]. In the university context, specifically, a study showed that perceived external prestige positively affected students' supportive attitudes toward the university [37]. Based on the presented, two hypotheses are formulated:

H4. Positive attitude towards university management will have a positive impact on perceived external prestige.

H5. Perceived external prestige will have a positive impact on students' university commitment. 


\subsection{Smart Governance}

Authors define governance as interaction and collaboration between different stakeholders in decision-making processes [39]. Creating a collaborative environment (smart collaboration) is believed to be a prerequisite for smart governance concepts [40]. Characteristics such as openness and transparency of decision-making and actions, open information sharing, stakeholder participation and collaboration, leveraging operations and services via intelligent and integrated technology use, as well as organization's role of facilitator of innovation, sustainability, competitiveness, and livability are used to define smart and open government [41], and as a subset of it, smart governance. It plays an essential role in providing transparent informationsharing mechanisms, among other benefits [42] and using ICT offers the opportunity to know, understand, and govern problems [43]. Smart universities must implement smart governance solutions with foci on [23]: (1) enabling governance on multiple stakeholder levels, (2) implementing work plans, (3) improving organizational performances and (4) presenting management workflow which supports automated reporting. Good governance in the context of HE refers to the concept of shared governance or distributed leadership, a principle that requires the participation of numerous stakeholders in the decision-making processes of universities [44]. Different stakeholders' expectations are mediated in smart university, ensuring the success of complex but cohesive and co-administered governance [45]. Various aspects of smart governance (for example, transparent communication via the web and mobile applications, resource sharing-booking) are explored in the paper. Four hypotheses are formulated:

H6. Smart governance will have a positive impact on students' university commitment.

H7. Smart governance will have a positive impact on the perception of fellow students of the university.

H8. Smart governance will have a positive impact on the positive attitude towards university management.

H9. Smart governance will have a positive impact on perceived external prestige. Figure 1 illustrates the hypothesized links between the five proposed constructs.

\section{Data and Methods}

\subsection{Participants and Data Collection}

The study participants were the first-year students of the University in Split, Faculty of Economics, Business and Tourism. The respondents come from a relatively homogeneous group (first-year students) and share a similar background in education and economic situations. However, a slight gender imbalance is observed as there are approximately $70 \%$ of female respondents and $30 \%$ of male respondents, yet this is consistent with the enrolled students' structure. 


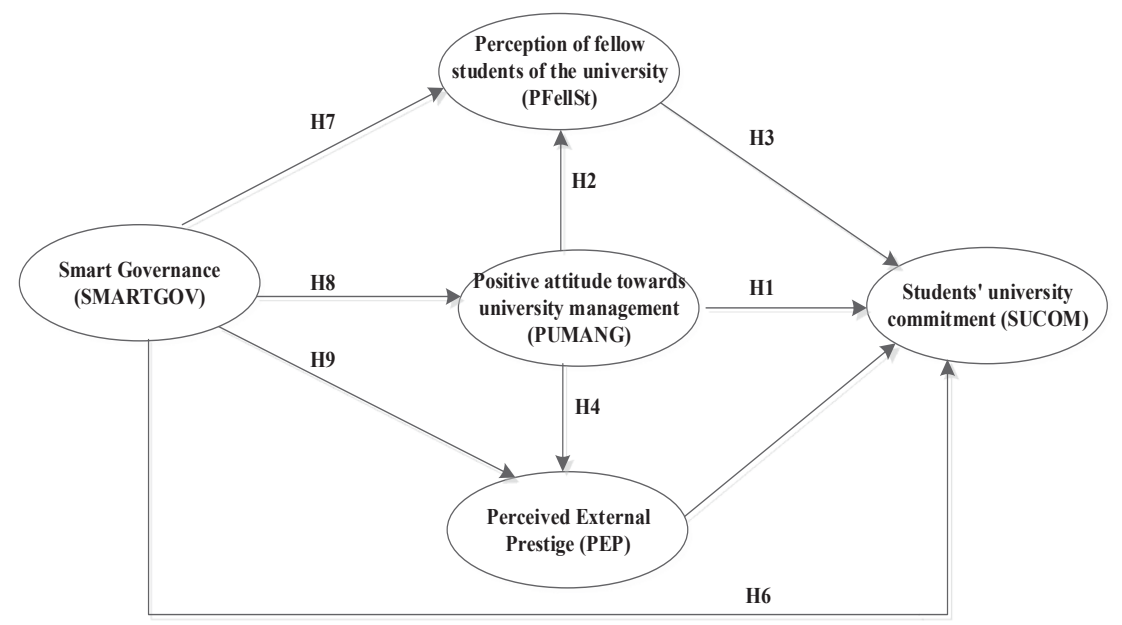

Figure 1. Proposed research model (extended and adapted from Udir Mišič and Podnar [9])

Data was collected in late October 2019 using an online survey tool (Lime Survey). Students completed the questionnaires voluntarily and anonymously, in computer labs and under a teaching fellow's supervision. They were instructed to access the link to the online questionnaire placed in the e-learning system. It took students approximately 15 minutes to complete it, and there were 411 completed questionnaires.

\subsection{Instrument}

For the survey, two instruments were used to measure students' perceptions of a university and its smart dimensions. The way the instruments were constructed, adapted and tested is presented in detail in another paper [6]. The first instrument measuring students' perceptions was based on construct names and 15 statements that have been contextualized for the university setting, instead of city context as it was originally proposed in the model by Udir Mišič and Podnar [9]. Variables have been contextualized as follows: city $=$ university, resident $=$ student, live $=$ study, people $=$ colleagues, tourists $=$ visiting students and scholars. The second instrument, with 18 statements, was based on smart city characteristics classification by Giffinger et al. [10] (3 questions per category). Exploratory factor analysis was used to test the construct validity of new instruments and reliability using Cronbach's Alpha. After removing one item from the first and one item from the second instrument, both presented factor structures are valid. For this paper, from the second instrument, only Smart governance construct and related scales were used as is already presented in the theoretical background.

\subsection{Structured Equation Modeling (SEM)}

Structural equation modeling (SEM) is a multivariate statistical analysis technique, a combination of factor analysis and path analysis. Part of the model that refers to 
measuring is equivalent to factor analysis and interpretation or relationship between latent and manifest variables, while the structural part corresponds to path analysis and interpretation of direct and indirect effects between latent variables [46]. The error related to manifest variables presents measurement error, reflecting the suitability of manifest variable for measuring related latent factors. The structural equation model is flexible and comprehensive, defining the relationship between dependent and independent variables (whether they are manifest or latent). This enables statistical evaluation, including multiple regression weight, factor analysis and multivariate ANOVA (MANOVA) [47]. The convergent and discriminant validity of the model was tested using confirmatory factor analysis and other relevant calculations and coefficients (Cronbach's alpha, Composite reliability, Average variance extracted, square root of AVE). The overall structural model contained 5 latent and 16 manifest variables presented further in the paper.

\section{Results}

\subsection{Descriptive Statistics and Assessment of Normality}

Before the reliability and validity testing of the measurement model, a normality test was performed based on skewness and kurtosis values. According to Hair et al. [48], if the number is higher than +1 or lower than -1 for skewness or kurtosis, distributions are considered not normal. Following the stated criteria, the variable "PEP4 - The University in which I study is considered reputable" has been excluded from further analysis. Descriptive statistics and assessment of normality are presented in Table 1.

\begin{tabular}{|l|c|c|c|c|c|c|}
\hline Variable & Min & Max & Mean & SD & Skew & Kurtosis \\
\hline PEP4 & 1.00 & 5.00 & 4.23 & 0.875 & -1.177 & 1.360 \\
\hline PEP3 & 1.00 & 5.00 & 4.01 & 0.942 & -.0677 & -0.154 \\
\hline PEP2 & 1.00 & 5.00 & 3.92 & 0.962 & -0.691 & 0.073 \\
\hline PEP1 & 1.00 & 5.00 & 3.58 & 1.107 & -0.524 & -0.423 \\
\hline SGOV2 & 1.00 & 5.00 & 3.92 & 0.814 & -0.237 & -0.414 \\
\hline SGOV3 & 1.00 & 5.00 & 4.17 & 0.749 & -0.602 & 0.138 \\
\hline SGOV1 & 1.00 & 5.00 & 3.91 & 0.948 & -0.778 & 0.453 \\
\hline PUM3 & 1.00 & 5.00 & 3.88 & 0.861 & -0.614 & 0.635 \\
\hline PUM2 & 1.00 & 5.00 & 3.83 & 0.848 & -0.424 & -0.014 \\
\hline PUM1 & 1.00 & 5.00 & 3.90 & 0.775 & -0.195 & -0.381 \\
\hline SUC4 & 1.00 & 5.00 & 3.90 & 0.963 & -0.609 & 0.005 \\
\hline SUC3 & 1.00 & 5.00 & 4.14 & 0.862 & -0.829 & 0.474 \\
\hline SUC2 & 1.00 & 5.00 & 3.93 & 0.969 & -0.809 & 0.501 \\
\hline SUC1 & 1.00 & 5.00 & 4.03 & 0.894 & -0.631 & -0.014 \\
\hline
\end{tabular}




\begin{tabular}{|l|c|c|c|c|c|c|}
\hline Variable & Min & Max & Mean & SD & Skew & Kurtosis \\
\hline PFSU3 & 1.00 & 5.00 & 4.12 & 0.826 & -0.774 & 0.526 \\
\hline PFSU2 & 1.00 & 5.00 & 3.81 & 0.893 & -0.442 & -0.033 \\
\hline PFSU1 & 1.00 & 5.00 & 4.08 & 0.776 & -0.551 & 0.220 \\
\hline
\end{tabular}

Table 1. Descriptive statistics and assessment of normality

\subsection{Reliability and Validity of the Measurement Model}

When selecting the number of manifest variables included in the model, the ratio of the sample size and the number of parameters were taken into account. Authors Hair et al. [49] suggest that the minimum sample size is 150 respondents for models containing 7 or fewer latent variables - each having 3 or more manifest variables with moderate variance projection on a relevant latent variable (0.5). Since the number of respondents is adequate $(\mathrm{N}=411)$, there was no need for reducing the number of latent and manifest variables. Cronbach's alpha coefficient for reliabilities was calculated, showing the internal consistency of items measuring the same construct [47]. There are varying opinions related to the acceptability of constructs based on alpha coefficients - Felder and Spurlin [50] consider $\alpha=0.5$ as a lower limit for acceptance, while [51] suggests it is 0.7 . Another criterion, such as a minimum sample size of 300 , is emphasized [52], or even 400 respondents required to have a reliable estimation of Cronbach's alpha coefficients. Cronbach's alpha for each construct was above 0.7 (Table 3), indicating high reliability.

\begin{tabular}{|c|c|c|c|}
\hline Abbrev. & Manifest variables & FL & $\begin{array}{l}\text { Corresponding } \\
\text { latent variable }\end{array}$ \\
\hline SUC1 & $\begin{array}{l}\text { At the university where I study, I will continue to } \\
\text { study, because I love my university. }\end{array}$ & 0.912 & \multirow{4}{*}{$\begin{array}{l}\text { Students' } \\
\text { university } \\
\text { commitment } \\
\text { (affective } \\
\text { commitment) } \\
\text { (SUCOM) }\end{array}$} \\
\hline SUC2 & $\begin{array}{l}\text { I wish to continue to study at this university because } \\
\text { I enjoy it. }\end{array}$ & 0.859 & \\
\hline SUC3 & $\begin{array}{l}\text { I would like to continue to study at the university } \\
\text { where I study now because it makes me feel good. }\end{array}$ & 0.875 & \\
\hline SUC4 & $\begin{array}{l}\text { At the university where I study, I will continue to } \\
\text { study, because this is the best place for me and my } \\
\text { family. }\end{array}$ & 0.781 & \\
\hline PEP1 & $\begin{array}{l}\text { Students of other universities think highly of the } \\
\text { university where I study. }\end{array}$ & 0.754 & \multirow{3}{*}{$\begin{array}{l}\text { Perceived external } \\
\text { prestige (PEP) }\end{array}$} \\
\hline PEP2 & $\begin{array}{l}\text { It is believed that it is good to study at the university } \\
\text { where I study. }\end{array}$ & 0.882 & \\
\hline PEP3 & $\begin{array}{l}\text { It is believed that the university where I study is one } \\
\text { of the most prestigious in the country. }\end{array}$ & 0.690 & \\
\hline PUM1 & $\begin{array}{l}\text { University management includes and takes into } \\
\text { account various disciplines regarding the } \\
\text { development of the university. }\end{array}$ & 0.830 & \multirow{2}{*}{$\begin{array}{l}\text { Positive attitude } \\
\text { towards university } \\
\text { management } \\
\text { (PUMANG) }\end{array}$} \\
\hline PUM2 & $\begin{array}{l}\text { University management encourages diverse } \\
\text { cultural, artistic and sports activities. }\end{array}$ & 0.757 & \\
\hline
\end{tabular}




\begin{tabular}{|c|c|c|c|}
\hline Abbrev. & Manifest variables & FL & $\begin{array}{l}\text { Corresponding } \\
\text { latent variable }\end{array}$ \\
\hline PUM3 & $\begin{array}{l}\text { The university management has a clearly defined } \\
\text { vision. }\end{array}$ & 0.755 & \\
\hline PFSU1 & $\begin{array}{l}\text { At the university where I study, colleagues show } \\
\text { solidarity with each other. }\end{array}$ & 0.751 & \multirow{3}{*}{$\begin{array}{l}\text { Perception of } \\
\text { fellow students of } \\
\text { the university } \\
\text { (PFellSt) }\end{array}$} \\
\hline PFSU2 & $\begin{array}{l}\text { Students of the university are in favor of and } \\
\text { friendly to visiting students and scholars. }\end{array}$ & 0.797 & \\
\hline PFSU3 & Students at the university where I study, feel safe. & 0.804 & \\
\hline SGOV1 & $\begin{array}{l}\text { University where I study implements new } \\
\text { technology and digital services for common } \\
\text { activities (such as communication with student } \\
\text { offices, for library services and similar). }\end{array}$ & 0.761 & \multirow{3}{*}{$\begin{array}{l}\text { Smart governance } \\
\text { (SMARTGOV) }\end{array}$} \\
\hline SGOV2 & $\begin{array}{l}\text { University where I study implements new } \\
\text { technology and digital services to increase } \\
\text { efficiency and effectiveness for management of } \\
\text { public campus infrastructure (e.g. signalization, } \\
\text { booking of campus resources and similar). }\end{array}$ & 0.750 & \\
\hline SGOV3 & $\begin{array}{l}\text { University where I study implements new } \\
\text { technology and digital services to achieve } \\
\text { transparent and trustworthy communication with all } \\
\text { stakeholders (primarily using the web and mobile } \\
\text { applications). }\end{array}$ & 0.731 & \\
\hline
\end{tabular}

Table 2. Results of confirmatory factor analysis (manifest and latent variables included in the SEM model and standardized factor loadings from AMOS model)

Convergent and discriminant validity of the scales was tested using confirmatory factor analysis. Convergent validity was checked using three tests (recommended by Anderson and Gerbing as cited in [53]): standardized factor loadings, composite reliabilities and average variance extracted. Standardized factor loadings of manifest variables in the model are obtained based on the confirmatory factor analysis done in AMOS based on the sample of 411 respondents. As presented in Table 2, all items loaded in the range from 0.690 to 0.912 and are statistically significant $(p<0,01)$, indicating a good measurement level of latent variables. Based on the criteria used for estimating composite reliability $(\mathrm{CR}) \geq 0,7$ and average variance extracted (AVE) $\geq$ 0,5 [54], there is only one construct (presented in Table 3) - Smart governance, that has $\mathrm{CR}=0.684$, deviating slightly from the satisfactory convergent validity scale. Bearing in mind that all other constructs have appropriate values of CR and AVE, and taking into consideration that value of Cronbach's alpha coefficient for the Smart governance construct is satisfactory (which can be used as an alternative measure for $\mathrm{CR}$ ), and adding that the construct has only three statements - construct was kept in for the purpose of discriminant validity testing. 


\begin{tabular}{|l|c|c|c|c|}
\hline Constructs & $\begin{array}{c}\text { Number } \\
\text { of items }\end{array}$ & $\begin{array}{c}\text { Cronbach's } \\
\text { alpha }\end{array}$ & $\begin{array}{c}\text { Composite } \\
\text { reliability } \\
\text { (CR) }\end{array}$ & $\begin{array}{c}\text { Average } \\
\text { variance } \\
\text { extracted } \\
\text { (AVE) }\end{array}$ \\
\hline $\begin{array}{l}\text { Students' university } \\
\text { commitment (SUCOM) }\end{array}$ & 4 & 0.916 & 0.918 & 0.736 \\
\hline $\begin{array}{l}\text { Perceived External } \\
\text { Prestige (PEP) }\end{array}$ & 3 & 0.816 & 0.713 & 0.608 \\
\hline $\begin{array}{l}\text { Positive attitude towards } \\
\text { university management } \\
\text { (PUMANG) }\end{array}$ & 3 & 0.822 & 0.717 & 0.611 \\
\hline $\begin{array}{l}\text { Perception of fellow } \\
\text { students of the } \\
\text { university (PFellSt) }\end{array}$ & 3 & 0.826 & 0.720 & 0.615 \\
\hline $\begin{array}{l}\text { Smart governance } \\
\text { (SMARTGOV) }\end{array}$ & 3 & 0.789 & 0.684 & 0.559 \\
\hline
\end{tabular}

Table 3. Results of reliability and convergent validity test

Table 4 presents the square root of AVE diagonally in bold emphasis and the correlation of pairs of latent variables (constructs) below the diagonal. The correlation of latent variables is lower than the square root of AVE for every pair of variables, confirming the discriminant validity of the scale. Consequently, the construct is regarded as distinct from other constructs since the criteria are met.

\begin{tabular}{|l|l|l|l|l|l|}
\hline Constructs & SUCOM & PEP & PUMANG & PFellSt & SMARTGOV \\
\hline SUCOM & $\mathbf{0 . 8 5 8}$ & & & & \\
\hline PEP & $0.537^{* *}$ & $\mathbf{0 . 7 8 0}$ & & & \\
\hline PUMANG & $0.511^{* *}$ & $0.520^{* *}$ & $\mathbf{0 . 7 8 2}$ & & \\
\hline PFellSt & $0.601^{* *}$ & $0.616^{* *}$ & $0.755^{* *}$ & $\mathbf{0 . 7 8 4}$ & \\
\hline SMARTGOV & $0.457^{* *}$ & $0.441^{* *}$ & $0.619^{* *}$ & $0.565^{*}$ & $\mathbf{0 . 7 4 8}$ \\
\hline
\end{tabular}

$* * \mathrm{p}<0.001$

Table 4. Results of discriminant validity test

\subsection{Structural Model Analysis}

Several relevant fit indices have been calculated and are presented in Table 5 to determine if the hypothesized model fits the analyzed data. Since there are a number of fit indices available, only the ones that provide enough information for model estimation have been chosen [49].

\begin{tabular}{|l|c|c|}
\hline Fit measure & Model value & Acceptable fit \\
\hline Comparative Fit Index (CFI) & 0.972 & $\geq 0.900$ \\
\hline RMSEA & 0.051 & $\leq 0.08$ \\
\hline AGFI (adjusted goodness-of-fit index) & 0.921 & $\geq 0.800$ \\
\hline
\end{tabular}




\begin{tabular}{|l|c|c|}
\hline GFI (goodness-of-fit index) & 0.945 & $\geq 0.900$ \\
\hline Chi-square & 195.893 & \\
\hline Degrees of freedom & 95 & \\
\hline Probability level & 0.000 & $\mathrm{P} \geq 0.05$ \\
\hline Chi-square/Degrees of freedom & 2.062 & $<3.00$ \\
\hline
\end{tabular}

Table 5. Overall model fit indices for the research model

Given that all values of analyzed indices are within acceptable ranges, it can be concluded that the defined model is suitable for further structural analysis.

\begin{tabular}{|l|c|c|c|l|}
\hline \multicolumn{1}{|c|}{ Constructs' relationship } & $\begin{array}{c}\text { Standardized } \\
\text { regression } \\
\text { weight }\end{array}$ & $\begin{array}{c}\text { Critical } \\
\text { Ration } \\
\text { (C. R.) }\end{array}$ & $\begin{array}{c}\text { p } \\
\text { values }\end{array}$ & $\begin{array}{c}\text { Hypothesis } \\
\text { supported }\end{array}$ \\
\hline PUMANG $\rightarrow$ SUCOM & 0.030 & 0.291 & 0.771 & $\begin{array}{l}\text { H1 - Not } \\
\text { supported }\end{array}$ \\
\hline PUMANG $\rightarrow$ PFellSt & $0.696^{* *}$ & 9.295 & 0.000 & H2 - Supported \\
\hline PfellSt $\rightarrow$ SUCOM & $0.355^{* *}$ & 3.765 & 0.000 & H3 - Supported \\
\hline PUMANG $\rightarrow$ PEP & $0.463^{* *}$ & 6.027 & 0.000 & H4 - Supported \\
\hline PEP $\rightarrow$ SUCOM & $0.270^{* *}$ & 4.474 & 0.000 & H5 - Supported \\
\hline SMARTGOV $\rightarrow$ SUCOM & 0.121 & 1.792 & 0.073 & $\begin{array}{l}\text { H6 - Not } \\
\text { supported }\end{array}$ \\
\hline SMARTGOV $\rightarrow$ PFellSt & $0.141^{*}$ & 2.140 & 0.032 & H7 - Supported \\
\hline SMARTGOV $\rightarrow$ PUMANG & $0.621^{* *}$ & 9.897 & 0.000 & H8 - Supported \\
\hline SMARTGOV $\rightarrow$ PEP & $0.164^{*}$ & 2.188 & 0.029 & H9 - Supported \\
\hline
\end{tabular}

${ }^{*} \mathrm{p}<0.05 ; * * \mathrm{p}<0.001$

Table 6. Results of the structural model and hypotheses testing

As presented in Table 6 and Figure 2, all of the path coefficients have a positive effect, and seven of them are statically significant with an associated p-value lower than 0.05. Exceptions are the path leading from the Positive attitude towards university management to Students' university commitment and path from Smart governance to Students' university commitment; even though the effects are positive, they are not statically significant (H1 and H6 are not supported by the results). Results show the significant and positive effect of Smart governance on Perception of fellow students (0.141), Positive attitude towards university management (0.621) and Perceived External Prestige (0.164) - H7, H8, and H9 are thus supported. The highest effect is on Positive attitude towards university management, which is significant at level $\mathrm{p}>0,001$. Furthermore, the effect of Positive attitude towards university management on Perceived External Prestige (0.463), as well as on the Perception of fellow students $(0.696)$, is high and significant $(\mathrm{p}<0.001)-\mathrm{H} 4$ and $\mathrm{H} 2$ are also supported. In addition, the effect of the Perception of fellow residents $(0.355)$ and Perceived External Prestige (0.270) on Students' university commitment are moderate 
and significant $(\mathrm{p}<0.001)-\mathrm{H} 3$ and H5 are also supported. On the contrary, the effect of the Positive attitude towards university management on Students' university commitment, with a path coefficient of 0.03 is low, and has no significant effect, the same as the path from Smart governance to Students' university commitment (0.121). Results of the structural model analysis by Udir Mišič and Podnar [9] showed very similar results regarding the path leading from Perception of city management to Citizens' commitment, i.e. the path coefficient was also low and not significant for both cities.

In brief, the results demonstrate that the Perception of fellow students and Perceived External Prestige mediate the correlation between constructs Smart governance and Students' university commitment. Both Perceived External Prestige and the Perception of fellow students are significant drivers of Students' university commitment. Positive attitude towards university management had a significant effect on Perceived External Prestige and Perception of fellow students but, surprisingly, had no significant direct effect on Students' university commitment.

Squared Multiple Correlation is the communality estimate for an indicator variable. The estimated value measures the percent of the variance in a given indicator variable explained by its latent variable (factor); the results are shown in Table 7.

\begin{tabular}{|l|c|}
\hline Construct & Estimate \\
\hline PUMANG & 0.377 \\
\hline PEP & 0.336 \\
\hline PFellSt & 0.627 \\
\hline SUCOM & 0.412 \\
\hline
\end{tabular}

Table 7. Squared Multiple Correlations

Figure 2 illustrates the validated research model with path coefficients and the significance of each relationship $(* p<0.05 ; * * p<0.001)$. The model also includes calculated variances R2 (from table 7) for each independent variable.

\section{Discussion}

This study aimed to examine the antecedents of students' university commitment. Specifically, the intention was to explore the level and the relation of one smart university feature - smart governance to the Positive attitude towards university management, Perception of fellow students, and Perceived External Prestige (PEP) as antecedents of university affective commitment. To the best of our knowledge, a study focusing on these constructs and in this form has not been conducted in the university context. The survey was conducted at the University of Split, the second biggest university in Croatia, composed of eleven faculties, one academy of arts and four university departments.

The study confirmed that, in the given context, Smart governance has positive effects on students' perceptions (Perception of fellow students, Positive attitude 
towards university management and Perceived External Prestige). Smart governance is characterized by openness, transparency, participation and collaboration [41].

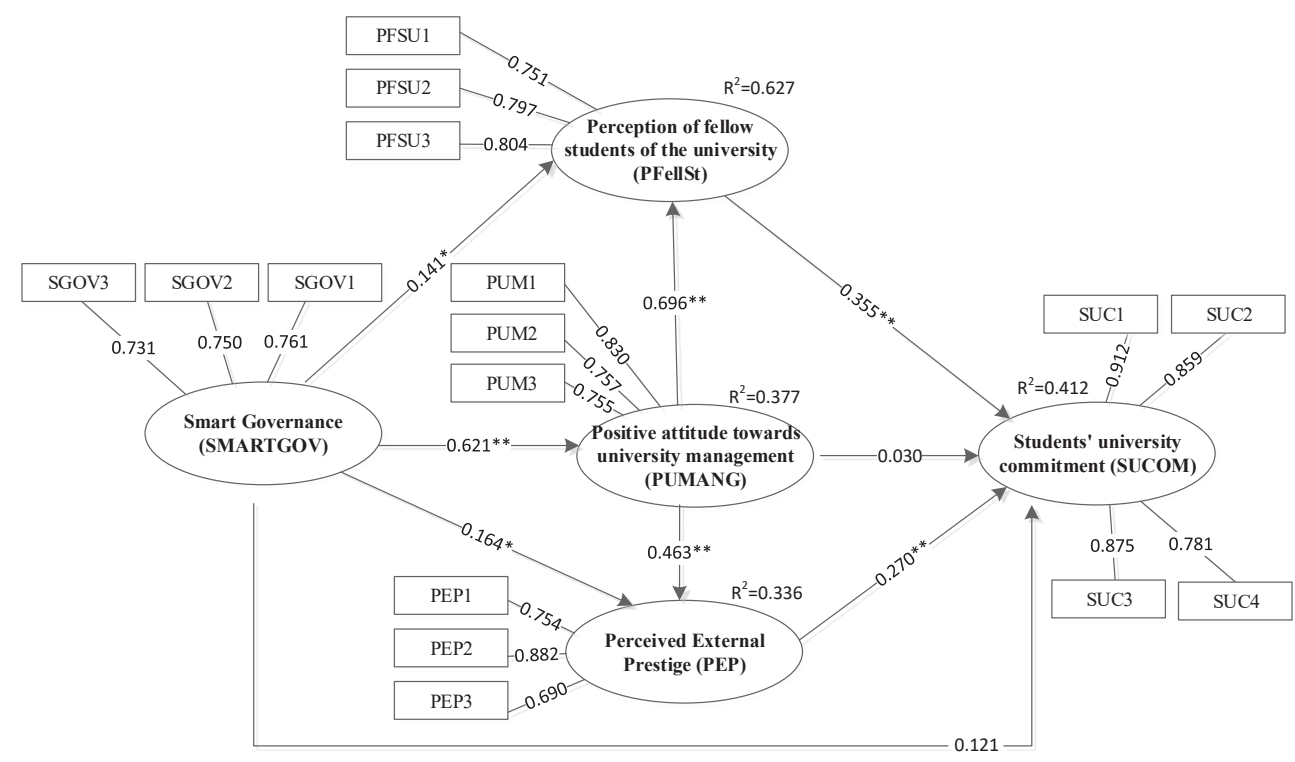

Figure 2. Validated final structural model

The strongest impact is on the Positive attitude towards university management (0.621), reflecting its importance. It is not enough only to use the technology that makes universities smart, but the universities also have to manage and facilitate the creation of smart human social capital and support innovative investments fostering synergies between teaching and research [2]. The same authors acknowledge that the smart university also has less bureaucracy [2], which would surely have a positive impact on students nowadays. Even though previous studies have demonstrated that the level of students' commitment rises when students have more opportunities and when they feel like they have become relevant stakeholders [12]), the results from this study surprisingly show a week correlation between Smart governance and Students' university commitment. Smart governance does, however, have an indirect impact on Students' university commitment through the Perception of fellow students and Perceived External Prestige. The results are consistent with the theoretical background when explaining the link between the Perception of fellow students and Students' university commitment similar to studies that demonstrate that the opinion of close people influences the decision to maintain the relationship and stay affiliated to the university [29], [16], [30]. Positive and significant effect of Perceived External Prestige on Students' university commitment was expected in line with other studies that indicate that the external prestige leads to individuals' affective commitment [38, 34]. This would mean that students who believe that individuals from outside the university have reasonable opinion about it would develop affective commitment. 
In relying on first-year students' feedback when they state, "I wish to continue to study at this university because I enjoy it" or "University management includes and takes into account various disciplines regarding the development of the university", one has to be cautious. It comes as no surprise that the strongest relationship is observed between the Positive attitude towards university management and the Perception of fellow students (0.696) since students form a strong opinion based on their experience (not just from the university but also from school). In that context, it is not surprising that the correlation between the Positive attitude towards university management and Students' university commitment is low and not significant, leaving the gap for future research: more focus has to be put on examining that relationship to see whether any other constructs could contribute to the explanation. University management considers a lot of aspects in order to improve efficiency, increase education quality and satisfy the needs of students, and as a result, it has an impact on student's attitudes towards the university as well as on how prestigious the organization is in the eyes of external individuals. If university management works well, it manifests to both Perception of fellow students (they will be satisfied) and Perceived External Prestige (outside individuals would have a good opinion about the university due to, for example, good university rankings or accreditations and similar). University outputs are the results of university management.

The limitation of this study is that the participants were limited to first-year students. There are plans to survey students from senior years to see how years of study affect their opinions. Also, gender imbalance among participants represents a limitation; however, these results are consistent with the institutional enrolment data. For future research, it would also be interesting to conduct this same study in other universities in Croatia and other European universities and compare the results. Due to the aforementioned limitations, one could not generalize the results without caution.

\section{Conclusion}

By addressing the relationships across selected constructs, this quantitative research contributes to growing research on smart universities. This paper seeks to contribute an understanding of how university management, using smart technologies, can increase university commitment and students' perceptions. Results showed that Smart governance has a positive impact on the Perception of fellow students of the university, Positive attitude towards university management and Perceived External Prestige. Smart governance also has an indirect impact on Students' university commitment (through Perception of fellow students and Perceived External prestige). Results also confirm that a Positive attitude towards university management positively correlates with Perceived External Prestige and Perception of fellow students of the university. Both Perceived External Prestige and the Perception of fellow students also have a positive impact on Students' university commitment. However, the relationship between a Positive attitude towards university management and Students' university commitment is not significant, so a Positive attitude towards university management influences affective commitment only through the aforementioned constructs. Smart governance has a highly positive and significant effect on students' 
perceptions, meaning that interaction, transparency, and inclusion in the decisionmaking processes and taking into consideration all stakeholders in resource management can be vital for improving students' experiences. Improving experiences for students and staff is one of the reasons why universities tend to become smart [8]. The practical implication of this study would be that finding antecedents of university commitment would help universities to achieve one of their main goals - attract and retain the best students and staff from around the globe [7]. In the process, the issues that universities need to study in-depth are how to use available technologies, improve user experience, optimize teaching methods, and improve teaching efficiency and effectiveness [24]. The role of University management cannot be neglected. For example, there is a lot to improve: introduce frequent and transparent communication on university achievements, projects, and other outputs and more.

\section{Acknowledgements}

This research was supported by the Croatian Science Foundation [grant number UIP2017-05-7625].

\section{References}

[1] E. Smyrnova-Trybulska (ed.), "E-learning and Smart Learning Environment for the Preparation of New Generation Specialists". Seria on E-learning. Katowice-Cieszyn. Vol. 10. 2018.

[2] M. Coccoli, A. Guercio, P. Maresca, and L. Stanganelli, "Smarter universities: A vision for the fast changing digital era," J. Vis. Lang. Comput., vol. 25, no. 6, pp. 1003-1011, 2014.

[3] M. Coccoli, P. Maresca, L. Stanganelli, and A. Guercio, "An experience of collaboration using a PaaS for the smarter university model," J. Vis. Lang. Comput., vol. 31, pp. 275-282, 2015.

[4] Ministarstvo, znanosti obrazovanja i sporta, "Strategija obrazovanja, znanosti i tehnologije," MZOS, Zagreb, Croatia, Oct. 2014.

[5] Sveučilište u Splitu, "Strategija 2015-2020,", Split, Croatia, Oct. 2015.

[6] M. Jadrić and M. Ćukušić, "Constructing and testing instruments for measuring students' perceptions of a university and its smart dimensions" in for 49th International Scientific Conference on Economic and Social Development "Building Resilient Society", 2019, pp. 13-14

[7] O. Akhrif, Y. E. B. El Idrissi, and N. Hmina, "Smart university: SOCbased study," in ACM International Conference Proceeding Series, 2018.

[8] T. Sutjarittham, H. H. Gharakheili, S. S. Kanhere, and V. Sivaraman, "Realizing a Smart University Campus: Vision, Architecture, and 
Implementation," Int. Symp. Adv. Networks Telecommun. Syst. ANTS, vol. 2018-Decem, 2019.

[9] K. Udir Mišič and K. Podnar, "Perception of city management, fellow residents, and Perceived External Prestige (PEP) as antecedents of city affective commitment - The city marketing perspective", Cities, vol. 84, pp. 66-74, 2019.

[10] R. Giffinger, C. Fertner, H. Kramar, R. Kalasek, N. Pichler-Milanovic and E. Meijers, Smart Cities - Ranking of European medium-sized cities, Vienna University of Technology, 2007.

[11] L. C. Strauss and J. F. Volkwein, "Predictors of Student Commitment at Two-Year and Four-Year Institutions," J. Higher Educ., vol. 75, no. 2, 2004.

[12] Y. Chen, "The relationships between brand association, trust, commitment, and satisfaction of higher education institutions", International Journal of Educational Management, vol. 31(7), pp. 973-985, 2017.

[13] B. Nguyen, X. Yu, T. C. Melewar, and J. Hemsley-Brown, "Brand ambidexterity and commitment in higher education: An exploratory study," J. Bus. Res., vol. 69, no. 8, pp. 3105-3112, 2016.

[14] M. Jadric, Ž. Garača and M. Ćukušić, "Student dropout analysis with application of data mining methods," Management, vol. 15, no. 1, pp. 3146, 2010.

[15] A. Japutra, K. Keni, and B. Nguyen, "What's in a university logo? Building commitment in higher education," J. Brand Manag., vol. 23, no. 2, pp. 137-152, 2016.

[16] F. Cownie, "'What drives students' affective commitment towards their university?'," J. Furth. High. Educ., vol. 43, no. 5, pp. 674-691, 2019.

[17] V. Tinto, "Dropout from higher education: a theoretical synthesis of recent research", Review of Educational Research, vol. 45(1), pp. 89-125, 1975.

[18] K. G. Love and A. P. Stemer, "Commitment to the University as Defined by the Allen and Meyer Model: Student-Athlete Versus NonstudentAthlete Differences," J. Coll. Student Retent. Res. Theory Pract., p. $152102511987988,2019$.

[19] Y. Barlas and V. G. Diker, "A dynamic simulation game (UNIGAME) for strategic university management," Simul. Gaming, vol. 31, no. 3, pp. 331$358,2000$.

[20] I. Chiyón, M. Palma, and A. Cazorla, "An approach of the European Higher Education Framework to the management of higher education at university level in Peru," Procedia - Soc. Behav. Sci., vol. 15, pp. 586-591, 2011. 
[21] N. Aion, L. Helmandollar, M. Wang, and J. W. P. Ng, "Intelligent campus (iCampus) impact study" in Proc. 2012 IEEE/WIC/ACM Int. Conf. Web Intell. Intell. Agent Technol. Work. WI-IAT 2012, pp. 291-295, 2012.

[22] Du, F. Meng, and B. Gao, "Research on the application system of smart campus in the context of smart city," in Proceedings - 2016 8th International Conference on Information Technology in Medicine and Education, ITME 2016, 2017, pp. 714-718.

[23] W. Muhamad, N. B. Kurniawan, S. Suhardi, and S. Yazid, "Smart campus features, technologies, and applications: A systematic literature review" in 2017 Int. Conf. Inf. Technol. Syst. Innov. ICITSI 2017 - Proc., vol. 2018Janua, no. October, pp. 384-391, 2018.

[24] M. Xiaocui, L. Peng, and W. Chumin, "Discussion on the Construction of College Smart Campus under the Background of Mobile Internet," no. Icamei, pp. 24-29, 2019.

[25] B. Valks, M. Arkesteijn, and A. Den Heijer, "Smart campus tools 2.0 exploring the use of real-time space use measurement at universities and organizations," Facilities, vol. ahead-of-p, no. ahead-of-print, 2019.

[26] N. Abishov, D. Asan, A. Kanat, and Z. Erkisheva, "Development of an Automated Information System University Management," Procedia - Soc. Behav. Sci., vol. 143, pp. 550-554, 2014.

[27] J. R. Hackman and W. S. Dysinger, "Commitment to College as a Factor in Student Attrition," Sociol. Educ., vol. 43, no. 3, p. 311, 1970.

[28] M. McGrath and A. Braunstein, "The prediction of freshmen attrition: an examination of the importance of certain demographic, academic, financial and social factors", College Student Journal, vol. 31(2), pp. 396-408, 1997.

[29] R. Bennett, "Determinants of Undergraduate Student Drop Out Rates in a University Business Studies Department," J. Furth. High. Educ., vol. 27, no. 2, pp. 123-141, 2003.

[30] V. Tinto, Leaving College: rethinking the causes and cures of student attrition,. Chicago, 1993.

[31] F. Nawaz, S. Shakeel, Z. Nawaz, and M. A. Hamza, “Acceptance of social fellow groups for learning: extension of technology assessment model (TAM)," vol. 13, no. 2, pp. 151-157, 2017.

[32] C. S. Areni, M. E. Ferrell, and J. B. Wilcox, "The persuasive impact of reported group opinions on individuals low vs. High in need for cognition: Rationalization vs. Biased elaboration?," Psychol. Mark., vol. 17, no. 10, pp. 855-875, 2000 . 
[33] C. Marsh, "Back on the bandwagon: The effect of opinion polls on public opinion”, Journal of Political Science, vol. 15(1), pp. 51-74, 1984.

[34] A. Smidts, A. T. H. Pruyn, and C. B. M. Van Riel, "The impact of employee communication and perceived external prestige on organizational identification," Acad. Manag. J., vol. 44, no. 5, pp. 10511062, 2001.

[35] J. B. Fuller, K. Hester, T. Barnett, L. Frey, C. Relyea, and D. Beu, "Perceived external prestige and internal respect: New insights into the organizational identification process," Hum. Relations, vol. 59, no. 6, pp. 815-846, 2006.

[36] A. Smidts, A. T. H. Pruyn, and C. B. M. Van Riel, "The Impact of Employee Communication and Perceived External Prestige on Organizational Identification" Acad. Manag. J., vol. 44, no. 5, pp. 1051$1062,2016$.

[37] M. Sung and S.-U. Yang, "Toward the Model of University Image: The Influence of Brand Personality, External Prestige, and Reputation," J. Public Relations Res., vol. 20, no. 4, pp. 357-376, 2008.

[38] S. K. Mishra, D. Bhatnagar, P. D’Cruz, and E. Noronha, “Linkage between perceived external prestige and emotional labor: Mediation effect of organizational identification among pharmaceutical representatives in India," J. World Bus., vol. 47, no. 2, pp. 204-212, 2012.

[39] R. G. Alonso and S. Lippez-De Castro, "Technology helps, people make: A smart city governance framework grounded in deliberative democracy" in Smarter as the new Urban Agenda, J. R. Gil-Garcia, T. A. Pardo, and T. Nam (Eds.), pp. 333-347. Springer International., 2016.

[40] G. Viale Pereira, M. A. Cunha, T. J. Lampoltshammer, P. Parycek, and M. G. Testa, "Increasing collaboration and participation in smart city governance: a cross-case analysis of smart city initiatives," Inf. Technol. Dev., vol. 23, no. 3, pp. 526-553, 2017.

[41] H. J. Scholl and M. C. Scholl, "Smart Governance: A Roadmap for Research and Practice," iConference 2014 Proc., no. 1, 2014.

[42] S. Alawadhi and H. J. Scholl, "Smart governance: A cross-case analysis of smart city initiatives," Proc. Annu. Hawaii Int. Conf. Syst. Sci., vol. 2016March, no. January, pp. 2953-2963, 2016.

[43] M. Azzari, C. Garau, P. Nesi, M. Paolucci, and P. Zamperlin, "Smart city governance strategies to better move towards a smart urbanism," Lect. Notes Comput. Sci. (including Subser. Lect. Notes Artif. Intell. Lect. Notes Bioinformatics), vol. 10962 LNCS, pp. 639-653, 2018. 
[44] W. Tamrat, "The exigencies of student participation in university governance: Lip services and bottlenecks," High. Educ. Q., no. March, pp. 1-13, 2019.

[45] C. Bassano, A. Carotenuto, M. Ferretti, Ma. C. Pietronudo, and H. E. Coskun, Smart University for Sustainable Governance in Smart Local Service Systems, vol. 787. Springer International Publishing, 2019.

[46] A. Halmi, Multivarijantna analiza u društvenim znanostima. Zagreb: Alineja, 2003.

[47] R. Ho, Handbook of univariate and multivariate data analysis and interpretation with SPSS, Taylor \& Francis Group, Chapman \& Hall/CRC, Boca Raton, 2006.

[48] J.F. Hair, G. T. M. Hult, C.M. Ringle and M. Sarstedt, A Primer on Partial Least Squares Structural Equation Modeling (PLS-SEM). 2nd Ed. Thousand Oaks, CA: Sage. 2017.

[49] J. F. Hair, W.C. Black, B.J. Babin, B.J. and R.E. Anderson, Multivariate Data Analysis, Pearson Prentice Hall, 2010.

[50] R.M. Felder and J. Spurlin, "Application, Reliability and Validity of the Index of Learning Styles”, International Journal of Engineering Education, vol. 21(1), pp. 103-112, 2005.

[51] R.B Kline, Principles and practice of structural equation modelling. Guilford Publications, New York, 2015.

[52] G. Shiral, M. Shekari and K.A. Angali, "Assessing Reliability and Validity of an Instrument for Measuring Resilience Safety Culture in Sociotechnical Systems", Safety and Health at Work, vol. 9(3), pp. 296-307, 2018.

[53] N.P. Rana, Y.K. Dwivedi, B. Lal, M.D. Williams and M. Clement, 'Citizens' adoption of an electronic government system: towards a unified view”, Information Systems Frontiers, vol. 19., pp. 549-568, 2017.

[54] C. Fornell and D.F. Larcker, "Evaluating structural equation models with unobservable variables and measurement error", Journal of Marketing Research, vol. 18(1), pp. 39-50, 1981. 